\title{
The Distribution of Zakat Fund to the Poor Entrepreneurs
} Using Micro Finance

Nurul llyana Muhd Adnan, Muhammad Adib Che Roselam, Zahri Hamat, Hafas Furqani

To Link this Article: http://dx.doi.org/10.6007/IJARBSS/v11-i2/8666

DOI:10.6007/IJARBSS/v11-i2/8666

Received: 11 December 2020, Revised: 08 January 2021, Accepted: 23 January 2021

Published Online: 13 February 2021

In-Text Citation: (Adnan et al., 2021)

To Cite this Article: Adnan, N. I. M., Roselam, M. A. C., Hamat, Z., \& Furqani, H. (2021). The Distribution of Zakat Fund to the Poor Entrepreneurs Using Micro Finance . International Journal of Academic Research in Business and Social Sciences, 11(2), 231-240.

\section{Copyright: (c) 2021 The Author(s)}

Published by Human Resource Management Academic Research Society (www.hrmars.com)

This article is published under the Creative Commons Attribution (CC BY 4.0) license. Anyone may reproduce, distribute, translate and create derivative works of this article (for both commercial and non-commercial purposes), subject to full attribution to the original publication and authors. The full terms of this license may be seen at: http://creativecommons.org/licences/by/4.0/legalcode

\section{Vol. 11, No. 2, 2021, Pg. 231 - 240}

Full Terms \& Conditions of access and use can be found at http://hrmars.com/index.php/pages/detail/publication-ethics 


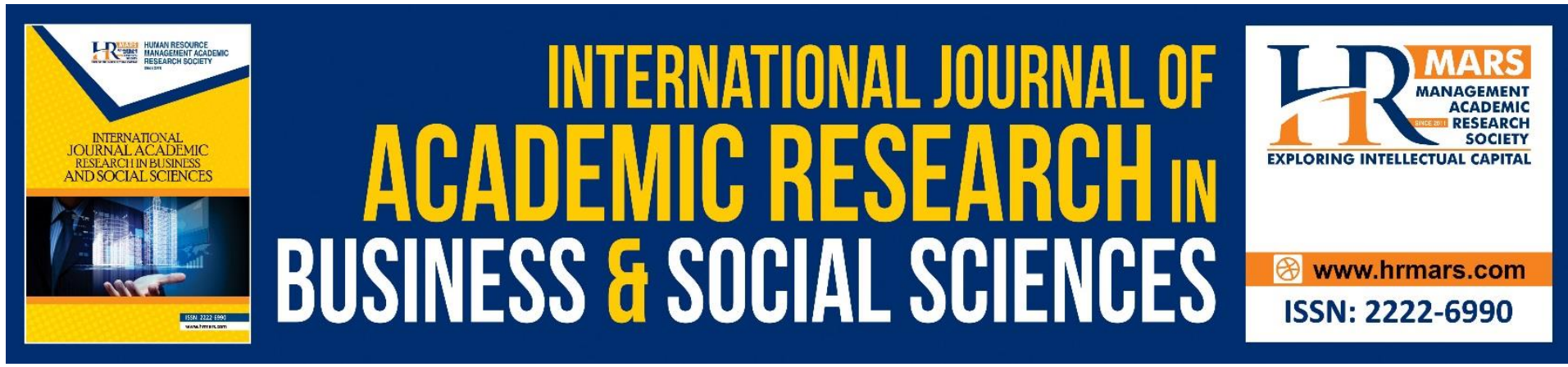

\title{
The Distribution of Zakat Fund to the Poor Entrepreneurs Using Micro Finance
}

\author{
Nurul Ilyana Muhd Adnan, Muhammad Adib Che Roselam¹, \\ Zahri Hamat ${ }^{2}$, Hafas Furqani ${ }^{3}$ \\ ${ }^{1}$ Faculty of Islamic Studies, Universiti Kebangsaan Malaysia, ${ }^{2}$ Universiti College Bestari \\ ${ }^{3}$ Universitas Islam Negeri Ar-Raniry
}

\begin{abstract}
Microfinance is one of the financial instruments for small and medium entrepreneurs to run a business. The constrains to obtain a capital often involving underprivileged entrepreneurs because it is difficult to get a fund from the financial institutions. Currently in Malaysia, Amanah Ikhtiar Malaysia (AIM) and TEKUN National are among the institutions that offer the native to obtain the business capital. Otherwise, the State Zakat Institution provides an assistance as a business capital by mean of "one-off" which does not require the borrowers to make a repayment at the end of the day. From a Muslim entrepreneur's perspective, micro finance that offered is consisting element of riba and it is prohibited in Islam. For that reason, seem that the financial assistance provided by zakat institutions is seen as unproductive and elective. Thus, micro-finance through zakat funds is an alternative proposition for unprivileged entrepreneurs. This article aims to analyze the readiness of zakat institutions in Malaysia to apply micro finance from zakat funds. The study is done using the case study method by conducting a semi-structured interview with 5 micro finance officers and 5 zakat officers from Zakat institutions. This study found that there is a tendency to apply micro finance from the zakat fund. In other words, zakat institutions in Malaysia are ready to implement zakat distribution by mean of micro finance. Hopefully, this study will be served as a reference for zakat institutions especially in Malaysia to practice micro finance from the zakat funds.
\end{abstract}

Keywords: Zakat, Zakat Institutions, Micro Credit, underprivileged Entrepreneurs , Productive Zakat

\section{Introduction}

Micro financing is one of the financial instruments for small entrepreneurs to run an enterprise, especially in the context of eradicating poverty. Micro finance from an Islamic perspective is fundamentally part of the concept of Islamic finance which provides noninterest-free lending (Nazirwan 2009). Studies have shown that there have been previous

\footnotetext{
${ }^{1}$ Faculty of Islamic Studies, Universiti Kebangsaan Malaysia

${ }^{2}$ Universiti College Bestari

${ }^{3}$ Universitas Islam Negeri Ar-Raniry
} 
studies on the implementation of micro financing for the poor and needy (underprivileged) in several countries and have been proven to overcome financial constraints (Ahmad 2004; Mannan, 2007; Adnan, 2015). The evidenced from the qardhul hasan micro-financing scheme in Iran which has successfully helped small farmers and traders (Ahmad 2004). In addition, the informal micro lending scheme in Bangladesh has helped small traders and shop owners solve financial constraints (Mannan, 2007). Adnan (2015) found that micro-lending business assistance in Baitul Mal Aceh has succeeded in changing the mustahiq life expectancy to betterment thus payments made within the stipulated period.

Positive effects are seen by increasing income, economic growth, assets and reducing vulnerability through micro finance to the poor (Obaidullah, 2008). However, the lenders who dominate in the sector come from banks, government agencies, development banks, and international agencies. In the context of the Islamic State, there is a religious-based financial institution with large funds, but it has not yet been utilized to offer micro financing for poor entrepreneurs among the poor, this reflects to the zakat institution.

Zakat funds can be administered in the form of investments, credit resources and can be given in the form of loans. The study by Adnan (2015) shows that the practice of Baitul Mal in Aceh has the potential to be practiced at a charity institution in Malaysia. Accordingly, the researcher argues that there should be a study on the mechanism for implementing the distribution of zakat fund in the form of micro credit. This article aims to analyze the readiness of zakat institution in Malaysia for micro-credit financing from a zakat fund.

\section{Micro Financing for Underprivileged Entrepreneurs in Malaysia}

Micro credit is a type of financing that offered to small-scale enterprises for business purposes only, such as financing round capital and purchasing fixed assets. The total rates offered are around RM 1000 to RM 50000 and it is not a personal financing (Bank Negara Malaysia, 2014). Micro- and small-scale financing serve as the backbone of economic development in most developing and less developed countries (Nirza \& Charbel, 2011). It also acts as a tool for eradicating poverty in third world countries (Khandaker, 2004). These low interest rates and do not require any collateral through micro credit lending help small businesses to obtain loans more easily than other banks that require high collateral rates and interest rates (Fig, 2004).

In the Malaysian context, bank and non-bank institutions provide venture capital assistance to involve in business and among the common forms of capital assistance provided by bank institutions are through micro financing schemes. However, the poor continue to be disregarded caused by the failure to obtain the funding. Among the factors that influencing this group are lack of capital, lack of adequate assurance and lack of strong assets (Raflis et al. 2017; Adnan 2015). Government institutions such as MARA and Development Bank (SME Bank) provide business assistance but the point is that they require the collateral while SME Bank provides more focused financing on medium and largescale projects and less focus on small and micro scale projects (Husmin et al., 2016).

While other than banking institutions, the business assistance also has been provided with conventional financial institutions Amanah Iktiar Malaysia dan Tekun Nasional (TEKUN). However, the transactions practiced by these two institutions are not free from the RIBA which is prohibited in Islam and cause partly of Muslim entrepreneur refuses to take it (Tahir 2010). While Rahim and Lokmanulhakim (2015) have expressed that loans from TEKUN concern in several Shariah issues such as in term of repayment, compulsory savings, 
management contributions, monthly repayment as well as the treaty is not free of the elements of Riba.

\section{Zakat Institution as the Poverty Eradication Instruments}

According to Islamic law, the distribution of zakat to those entitled to receive it has been established in the Qur'an (9:60) that is indigent, poor, zakat Amil, Muallaf who recently converted to Islam, slaves, who plagued debts, for the cause of Allah and those who were on the way.

Various efforts been made by the Zakat institutions in addressing poverty through economic development programs for the poor and needy. This economic development program aims to improve the socio-economic status of the poor and as a result, they are able to produce a self-reliant in entrepreneurship so that they no longer depend on Zakat (in the form of cash money) at all time (Alias, 2012). Through this program, assistance for the business capital is either in cash or equipment is given to the poor who are eligible and meet the criteria (Rahman et al., 2008).

Based on the reviewed results for the financial aid system provided by the Zakat institution, there are two major factors causing this financial assistance does not achieved the desired goal. First, from the standpoint of distribution of financial aid, the provided funds are forfeited and the repayment is not required even if the employer failed in business undertaken (Adnan, 2015). As a result, some recipients have no sense of responsibility for the assistance received (Ahmad, 2008; Rahman et. Al 2008). In addition, a shortage of labor and expertise, give a negative impact on the implementation of this financial assistance. Thus, the periodic monitoring is not possible to update the current developments. Secondly, in term of the beneficiaries, the poor. The attitude problem, skills and knowledge regarding to the business is the major problems encountered in this program (Rahman et al., 2014). Review Sanep et al. (2010) found that the institution of zakat or treasury does not have a specific procedure in setting the rate of zakat fund and it is determined on an ad-hoc thereby causing lack of capital among entrepreneurs' recipients.

\section{Potential of Zakat Institution as Financier of Micro Credit}

Zakat funds is seemed to have the potential to become one of the instruments to micro-credit to the poor. This is contrary to the opinion of some classic scholars who view Zakat as a direct grant and not as a business capital fund assistance. However, the improvement effort should be made to the proposed ljtihad in Zakat distribution of in the form of micro finance. The ijtihad is based on point of view by al-Qaradawi (1994) and Zarqa' (1987) that zakat can be refined according to current needs. This point of view is reinforced by a number of arguments.

First, for a Muslim, Zakat plays an important role in the development of socio economy in Islamic societies (Majid, 2003). Zakat is seen as an instrument in a position to eradicate poverty and reduce social and economic gaps between the rich and the poor (Halimi \& Zanariah, n.d.)

Secondly, the Zakat needs to be productive in their distribution. The distribution of Zakat in the form of productive capital can be allocated for the working capital through two forms. First, in cash money and equipment. For example, by giving to the carpenter carpentry equipment. Dealers or traders are given business capital while the farmers were given land. Second, the amount of business capital is distributed to suit their respective fields. Vegetables traders were given capital by five to twenty dinars, one dinar to perfume sellers, five thousand 
dinar to money changers and to the diamond industry allocated for ten thousand dinars (AlNawawi, 1996).

Third, Zakat can be expended in the form of investments for development. Based on the resolution of Majma 'al-Fiqh Islamiyy in 1986, which means:

"... Basically, Zakat property undertaken in investment projects is mubah (neutral in islamic law) where at the end will be owned by those who tithe receive zakat (mustahiq) or it is supervised by the certified parties in Islamic law and they are responsible for the collection and distribution of zakat. This requirement is provided immediately to the entitled recipients and adequately met the conditions and fulfill the guarantee that the loss can abide.

\section{Research Methodology}

This qualitative study uses a case study approach. Hence, the researchers conducted two methods of data collection, first is interviews with the focus groups, and second is in-depth semi-structured interviews. To maintain confidentiality and easier analysis, code PZ 1 to PZ 5 was used in the name of the study participants. Five people representing 4 zakat institutions from different states. All data interviews transcribed verbatim and analyzed manually with descriptive approach.

\section{Findings: Zakat Institution as Micro Credit Financier}

Various approaches used in zakat institutions for the distribution of zakat. Among the approach is through the productive distribution via entrepreneurial development programs to improve the living standards of the poor for the betterment (Azman et al., 2014). The productive zakat distribution given, seemed improving the lives of recipients for the better live as the revelation from informant PZ1:

"If we keep giving the money to them but until when ?, therefore we have to give something that can make them do effort on it later.I am toatally agree for the assistance is in the form of capital to entrepreneurs ".

The assistance given which does not require repayment would cause entrepreneurs recipients are not serious to manage the company they run. Based on studies by Nadzri (2016), the recipient entrepreneurs are more inclined towards financial failure compared to entrepreneurs from other financial institutions, Amanah Ikhtiar Malaysia.Factors influencing this failure is caused by there is no sense of responsibility from them. The Entrepreneurs feel zakat assistance are compassionate and do not have the pressure to repay back, compared to entrepreneurs from Amanah Ikhtiar Malaysia. From the above statement, there was a gap in the current distribution implemented by zakat institution in Malaysia. Consequently, a new alternative could be implemented for the provision of working capital through micro credit from the zakat funds.

Based on the resolution of the Discussion of the Round Table Application of Funds of Zakat in Takaful Micro and Micro-Credit 2018, zakat can be developed as a source for the provision of takaful micro financing and micro-credit to overcome the lack of injection for additional resources from the government. According to Ahmed (2003), welfare funds such as zakat and waqaf can be leveraged in the form of the micro; aims to fulfill the basic needs of the poorest and marketability can be improved with the provision of basic skills training, education, enterprenuership and the elements of the religious. Thus, zakah is potentially to be distributed in the form of micro-credit.

There are a number of important instruments to ensure the effectiveness of this program such as smart collaboration, training and skills, monitoring and selection of 
participants. Smart collaboration should be formed between government agencies, nongovernmental organizations, influential figures, private institutions, corporate and state and federal government. It is aimed to ensuring the aid program to the asnaf this successfully (Tarimin, 2011). This is parallel with with the view of the PZ 3 which states

"Can be realized with the cooperation of the smartphone is not just simply the institution of zakat but must be made the same working smart with financial institutions eg banks then takaful, AIM and the like"

(Interview of Research Partipants 3: 2019)

The smart collaboration between the institutions of zakat agencies and other authorities is aimed to monitoring the efficient and effective can be carried out (Ibrahim, 2011). This issue is seen very important because the institution of zakat is less experience in this system and need to adaopt the other institutions to avoid failure during monitoring session. The smart collaboration can be made from the aspects of the way the repayment to be effective, the expertise and experience to ensure the more effective.

Apart from the smart collaboration, the aspect of training skills and observation are also important to ensure the enterprise's success. Azman et al. (2014) found that among the factors of failure occurred in the system are due to the factor of monitoring and lack of knowledge as well as skills towards the company. Training skills is important because will give you exposure as well as knowledge in respect of the enterprise carried out.

According to Hussain Husain Syahatah, the periodic monitoring, basic courses, as well as skills should be emphasized to ensure that the funds of zakat did not wasted (Ibrahim, 2018). Researchers noticed that monitoring the entrepreneurs should demonstrate their business performance for the monitoring during the specified period, to encourage the attitude of responsiblity. The training would be able to increase productivity as well as provide exposure in respect of knowledge of the enterprise right. Besides, the selection of participants also should be emphasized. This is based on statements from the PZ1:

"Not all the asnaf we will receive so we set up a conditional selection to become an entreprenuer".

(Interview of Research Participants 1:2019)

Hence, aspects of the selection of participants is important to ensure it's successfulness. The institutions should set up some criterisa and conditions for applications. Only those who fulfilled the critirias and eligible recipients will be granted.

Contract and Category of The appropriate in-App Micro-Financing from the Funds of Zakat There are some contracts that are appropriate to be practiced in this application. According to Bahri (2011) there is a format that is appropriate in the micro-financing from the funds of zakat, they are qard al-hassan, murabahah, mudharabah and musyarakah mutanaqisah. This opinion is parallel with the views of the PZ2 and PZ3:

"There is a business entity, is actually owned by the Baitulmal based on the musyarakah mutanaqisah, once he succeeds, he can raise the percentage of ownership. When the business already belonged to him, whether he aimed to sell or not us up to him. Murabahah. Mudharabah are the most suitable in this due to the project based." (PZ 3)

(Interview of Research Participants 3: 2019)

"I'm prefer the qardhul-hassan without rejecting the other. Musyarakah is involves the institution."(PZ1)

(Interview of Reserach Partipants 1: 2019) 
Each contract offered is based on the suitability on the type of an enterprise. For example, with respect to business and education, the appropriate contract is qard al hassan. Qard al-hassan is in form of cash in the debt without being charged any interest rates even though the late payment charged (Naser \& Naser, 2011). Through the contract, the service fees can be charged against the borrower. Nevertheless, the rate of the service should be covered the entire actual cost of services (Rahim 2007). While, contract of mudharabah (profit sharing) is compatible with the project of manufacturing products in Small and Medium Industries (SMI). For the project of retailing, the purchase of equipment and tools machinery, the appropriate contract is musyarakah mutanaqisah (Tarimin 2011). Profits raised will be distributed according to the percentage agreed between the involved parties (Rahim 2007).

The implementation of the distribution is based on the current situation and the local based on the expediency of a general (Khafidz 2006). Some of the categories are appropriate in this kind of financing as expressed by PZ 2 and PZ 3:

"The poor, then ghārimin; those who loss a job and never have a profession. Finally is thoes who converts" (PZ 3)

(Interview of Research Participants 3:2019)

"Fuqara masakin also shall be"(PZ 2)

(Interview of Research Participants 2: 2018)

View PZ 1 and PZ 2 viewed parallel with the condition for poor. Qardhawi (1995:511) argues that zakat should be collected and distribution directly to the poor based on the hadith of preference in giving zakah which Muadh b. Jabal was appointed as a governor in Yemen. In other words, the fakir and the poor fit in this financing.

\section{The Focused Business Sector}

There are some areas potentially to be implemented for the micro credit from the funds of zakat, for example businesses, retailing, industrial, health and service. This is based on the view of the PZ 3:

"first is business, then retail, clothing industry food, retail industrial.

Health is seems to be hard. The other services are such as food grab"

(Interview of Research Participants 3:2019)

Adnan (2015) claimed that the business sector, agriculture, agro, industrial, naval, manufacturing, skills and education have the potential to be implemented in this kind of financing. The implementation suitable in the field of small enterprises because most of the entrepreneurs eligible recipients are involve in the small-scale project. The underprivilage entrepreneurs are need the sufficient capital as well as round capital to ensure that their enterprise continues to grow.

However, the focused implementation should be improve in various aspects such as knowledge, information as well as skills. Workshops skills should be done by the organizers to give exposure to involved the underprivilage entrepreneurs in terms of knowledge, right skills in enterprise. This is to ensure they are not lead to failure.

\section{The Readiness of The Implementation of Microfinance Credtt From The Funds Of Zakat}

The collection of zakat is seems to be increasing every year. It is showed that the institution of zakat has proved the effectiveness of the distribution (Wahid et al., 2004). There is a potential of willingness to grant on working capital from the funds of zakat through the financing of micro-credit. This willingness is based on the view of the PZ 3: 
"I as a practitioner of zakat and members in the industry, have seen the willingness of this need and it is something that ought to endeavor of the zakat. I strongly agree with the specific mechanism and the specific supervision. In the meantime, help in consumative is to be continued".(PZ 3)

(Interview of Research Participants 3:2019)

"The mechanisms are developed from time to time. The potential to grow can be seem after the implementation been practiced" (PZ 2)

(Interview of Research Participants 2: 2018)

The findings showed that Baitul Mal Aceh have been successfully implementing the program of business support in the form of micro-financing from the funds of zakat. The provided support are involved of three sectors, namely tradings, agriculture and services. It has been proved that this implementation can change the social status of the poor entrepreneur into better life and also where the payment transaction is successfully implemented for the prescribed period. This statement is strengthened further with the study by Hamat (2010), who stated that the transaction of repayment record collection exceeding 75 percent in 2010. As the result, lead to the sustainability in the distribution of zakat.

Based on the statement, the institutions of zakat are ready to implement this kind of financing. But there should be intensive preparations for monitoring and supervision in order to ensure this program is successfully implemented. Next is the help for consumptive as well as living support. Moral support and motivation from the institution of zakat is also been considered to increase awareness, in order improve their social life status into to the zakat payer in the future. Awareness and sense of responsibility towards the repayment of the loan should be applied by the institution of zakat in order to ensure the process of repayment in a specified period.

Based on the above discussion, the institution of zakat is ready to perform zakat distribution in the form of working capital through the financing of micro-credit. It is to avoid the eligible recipients among the entrepreneurs involved in usury from other financial institutions. This matter is not contrary to the maqasid syariah and also aims to avoid mafsadah. This funding is seen to have a good impact in the sustainability of zakat distribution. The charity also need empowerment as well as a professional management by having the expertise from the aspect of the development, research as well as embedding mechanisms such as partnership, skills, monitoring and participants. In addition, types of financing contracts must be appropriate. As a result, the society did not have a bad judgemental on the institution of zakat, therefore the collection of zakat will increase in future.

\section{Future Outlook: Zakat Microfinancing}

The study found that zakat can be implemened as a form on microfinance. It is very potential to help the underpriviliged ones. The support of micro-financing to them is the continuation of the financial inclusion agenda in a country, The concept of zakat can be implemented not only among Muslim countries but also all other developing countries. This is because zakat institutions have samilarities with community-based financial assistance. 


\section{Appreciation}

This article is part of the research findings of Distribution of Funds Charity Through MicroCredit Among Eligible Recipients Entrepreneurs in the Federal Territory under research grants GUP-2018-073.

\section{Corresponding Author}

Muhammad Adib Che Roselam

Centre for Contemporary Fiqh and Sharia Compliance, Faculty of Islamic Studies, Universiti Kebangsaan Malaysia

Email: mohdadibcr@gmail.com

\section{References}

Al-Nawawi. (1996). Al Majmu' Sharh al-Muhadhdhab lil Shirazi. Kaherah: Al-Matba'ah AlMisriyyah.

Rahim, A. R. A. (2007), Islamic Microfinance : A Missing Component in Islamic Banking, Kyoto of Islamic Area Studies 1-2, 38-53.

Rahman, A. A., Bashah, M. Y. A., Abdullah, M., Nooh, M. N., \& Fauzi, A. A. M. (2014). Keberkesanan Program Usahawan Asnaf Oleh Institusi Zakat dalam Menginterpretasikan Keharmonian Ummah. International Conference of Arabic Studies and Islamic Civilazation Icasic. Kuala Lumpur: Organized by World Conferences.net.

Ismawan, B. (2003), Merajut kebersamaan dan kemandirian bangsa melalui kewangan mikro; Untuk Menanggulangi Kemiskinan dan Menggerakkan Ekonomi Rakyat. Jurnal Ekonomi Rakyat 2(6), 105.

Nadzri, A. F. A. (2016). Critical Success Factors of Micro Entreprenuer Under The Amanah Ikhtiar Malaysia and Asnaf's Economy Development Programme. University Teknologi MARA.

Ahmad, H. (2004), Role of Zakah and Awqaf in Poverty Alleviation. Jeddah; Islamic Research and Training Institute, IDB.

Wahid, H., Ahmad, S., \& Noor, M. A. M. (2004). Kesan Bantuan Zakat Terhadap Kualiti Hidup : Kajian Kes Asnaf Fakir dan Miskin. The Journal of Muamalat and Islamic Finance Research (JMIFR) Vol. 1: 151-166.

Mannan. (2007). New Frontier of Islamic Micro-Finance and Voluntary Sector Banking and Finance. Seminar Proceeding on National Conference in Islamic Finance 2007, Faculty of Business and Accountancy, University Darul Iman.

Majid, A. M. Z. (2003). Pengurusan Zakat, hlm. Cetakan Pe. Kuala Lumpur: Dewan Bahasa dan Pustaka.

Alias, M. F. (2012). Zakat dan Pembangunan Asnaf :Kajian terhadap tahap pengetahuan, kemahiran dan sikap dalam keusahawanan dan perniagaan di Kedah. Kolej Universiti Insaniah.

Ibrahim, M. A. (2018). Pembiayaan Mikro dalam Kalangan Usahawan Asnaf di Lembaga Zakat Selangor (LZS). Universiti Sains Malaysia.

Husmin, M. R. A., Sabri, A. S., Rosli, H. F., Zakaria, N. A., Kassim, M. A. M., \& Suhaimi, A. F. M. (2016). Usahawan Mikro Kredit: Faktor-Faktor yang Mendorong Kejayaan Perniagaan. Proceeding of 2nd International Conference on Economics \& Banking 2016 (2nd ICEB), 24-25 May 204-215. doi:e-ISBN: 978-967-0850-40-5

Al-Zarqa', M. (1987). Majallah majma' al-fiqh al-islami. Jeddah: Majma' Al-Fiqh Al-Islami.

Nazirwan, M. (2009), Embracing The Islamic Community Based Microfinance for Poverty 
Alleviation. The Microbanker Website :http:/www.microbanker.com/(25 September 2011).

Ghani, N. A. N. A. R., \& Hussain, L. (2015). Analisis Prinsip Qard dalam Pinjaman Tekun. Isu Syariah \& Undang-undang Siri 21. Jabatan Syariah, Universiti Kebangsaan Malaysia.

Adnan, M. N. I. (2015). Mikro Kredit Daripada Dana Zakat di Baitul Mal Acheh dan Potensi Pelaksanaanya di Institusi-Institusi Zakat di Malaysia. Universiti Sains Malaysia.

Muhammed, O. (2008). Introduction to Islamic Microfinance. New Delhi: New Delhi ; International Institute of Islamic Business and Finance.

Rahman, A. R., Ahmad, S., \& Wahid, H. (2008). Perlaksanaan bantuan modal zakat: Analisis Perbandingan. Seminar Kebangsaan Ekonomi Malaysia. Kuala Lumput.

Ahmad, S. (2008). Bantuan Modal Zakat: Sumber Mikro Kredit. Prosiding Seminar Antarabangsa "Developing Regional Economy Through Networking:Role of Small Medium Enteprises (SME'S) 1-17.

Shahatah, I. S. (1989)."Limitations on the Use of Zakah Funds in Financing the Socio-Economic Infrastructure of Society." dlm I.A Imtiazi et. al. sunt., Management of Zakah in Modern Muslim Society, Jeddah; Islamic Research and Training Institute

Naser, S., \& Mohsin, A. (2011), Tajrubah al-Jazair Fi Tamwil al-Msyari' al-Musghrirah Bisighah. Warqalah al- Jajair, Jam'iyyah Qasadi al-Marbah.

Yusoff, S. A. (2016), January 21. Konflik Saudara Baru. Utusan Online. Kuala Lumpur. Retrieved from https://www.utusan.com.my/mega/agama/konflik-saudara-baharu-1.181880

Al-Qaradawi, Y. (1994). Fiqh az-zakat- dirasah muqaranah li ahkamiha wa falafatiha fi daw' al-Quran wa al-Sunnah. Beirut: Maktabah Al- Risalah.

Zahri, H. (2010). Kelestarian pengagihan dana zakat di baitul mal Aceh. International Seminar Economic Regional Development, Law and Governance in Malaysia and Indonesia 1-14. 